\title{
Article
}

\section{Decarbonization of Marine Fuels-The Future of Shipping}

\author{
Jerzy Herdzik (1)
}

check for updates

Citation: Herdzik, J. Decarbonization of Marine Fuels-The Future of Shipping. Energies 2021, 14, 4311. https://doi.org/10.3390/en14144311

Academic Editor: Jurgita Raudeliuniene

Received: 10 June 2021

Accepted: 15 July 2021

Published: 17 July 2021

Publisher's Note: MDPI stays neutral with regard to jurisdictional claims in published maps and institutional affiliations.

Copyright: (C) 2021 by the author. Licensee MDPI, Basel, Switzerland. This article is an open access article distributed under the terms and conditions of the Creative Commons Attribution (CC BY) license (https:/ / creativecommons.org/licenses/by/ $4.0 /)$.
Marine Propulsion Plants Department, Gdynia Maritime University, Morska 81-87, 81-225 Gdynia, Poland; j.herdzik@wm.umg.edu.pl; Tel.: +48-58-5586-430

\begin{abstract}
The goal of reducing the climate impact of shipping requires many different activities. To reduce greenhouse gas emissions, the International Maritime Organization prepared some proposals to meet and fulfill the requirements. It sets out the provisions of the International Convention for the Prevention of Pollution from Ships 73/78 Annex 6-Prevention of the Air Pollution from Ships (1997) with the amendments and the future objectives set. The main objective is to achieve climate neutrality from shipping by 2050. One method is the decarbonization of marine fuels. The types of fuels that are transient fuels, with the final target fuel being hydrogen, are shown. Carbon dioxide emissions depend on the chemical composition of the fuel, its Lower Heating Value and the engine efficiency. The aim of the manuscript is to demonstrate that the use of fuels with lower carbon content is a transitional process enabling the hydrogen era to take place. An analysis of this problem is presented as a review of the subject along with the author's comments and observations. The development of technologies for adapting potential fuels to combustion requirements in marine diesel engines and gas turbines, together with their storage and bunkering capabilities, are the main barriers to their limited use. The efficiency of marine diesel engines reaches a value of about $50 \%$, while that of fuel cells are close to $100 \%$. It seems that hydrogen will be the fuel of the future, including in shipping. Its basic use is in fuel cells, the efficiency of which is almost twice that of current thermal internal combustion engines.
\end{abstract}

Keywords: marine fuels; carbon dioxide emission; greenhouse gases; decarbonization process

\section{Introduction}

Cargo transport by sea is vital for the global economy. Additionally, ferries provide services in international, domestic and inland transport of lorries, cars and passengers. Probably after the COVID-19 pandemic passes, a fleet of cruise vessels will rejoin the tourist system. To fulfill their functions, all vessels need different types of energy, but the prime energy always comes from marine fuels (the share of renewable energy sources may be disregarded). The age of coal as a marine fuel came to an end over sixty years ago and will not come back. Now, liquid marine fuels derived from crude oil are mainly used. Oil-refinement processes produce a few types of marine fuels such as marine gas oil (MGO), marine diesel oil (MDO) and heavy fuel oils (HFO) [1] (ISO 8217). Marine diesel engines were adapted to burn residual fuels with a viscosity at $50{ }^{\circ} \mathrm{C}$ up to $700 \mathrm{cSt}$. Due to the following regulations [2-4], other biofuels for shipping have been introduced, such as the following: biodiesel, methanol, ethanol, biobutanol, bioethers, palm, vegetable or cooking oil, and others, but their share is limited to certain cases and places (i.e., inland transport) [5-8]. Of course, a few electric vessels (ferries) have been built that use electric energy from batteries, but the electric energy derived mainly from onshore power plants and the capacity of energy accumulation is still limited to short voyages. Ampere was the first inland passenger-car ferry put into operation in early 2015 [9]. The route it sails is only $6 \mathrm{~km}$. 


\section{Carbon Dioxide Emission from Shipping}

International shipping has been the reason behind the emission of about $2.5 \div 3 \%$ of carbon dioxide $\left(\mathrm{CO}_{2}\right)$ in the worldwide pollution. In 2015, it accounted for 932 million tons and $2.6 \%$ of emissions. All forms of transport account for $24 \%$ of global emission. Carbon dioxide emission depends on total fuel consumption and carbon concentration in the fuel used. $\mathrm{CO}_{2}$ is the one of greenhouse gases (GHG) [2]. Due to the emission of other GHGs such as nitrogen and sulfur oxides from marine diesel engines, equivalent $\mathrm{CO}_{2}\left(\mathrm{CO}_{2 \mathrm{e}}\right)$ emissions have sometimes been used. The inquired information includes the type of GHG, its content and the GWP indicator (Table 1).

Table 1. Global Warming Potential (GWP) indicators in the 20-year and 100-year horizons relative to $\mathrm{CO}_{2}$ for different greenhouse gases (GHGs) [10-12].

\begin{tabular}{ccc}
\hline Type of Gas & $\mathbf{G W P}_{\mathbf{2 0}}$ & $\mathbf{G W P}_{\mathbf{1 0 0}}$ \\
\hline Carbon dioxide $\mathrm{CO}_{2}$ & 1 & 1 \\
Carbon monoxide CO & $2.8 \div 10^{1}$ & $1 \div 3^{1}$ \\
Methane $\mathrm{CH}_{4}$ & 84 & 30 \\
Nitrous oxide $\mathrm{N}_{2} \mathrm{O}$ & 300 & 265 \\
Propane $\mathrm{C}_{3} \mathrm{H}_{8}$ & 9.5 & 3.3 \\
Butane $\mathrm{C}_{4} \mathrm{H}_{10}$ & 6.5 & 4 \\
Black Carbon $\mathrm{BC}$ & 4.47 & $1.055 \div 2.24^{1}$ \\
Ammonia $\mathrm{NH}_{3}$ & 0 & 0 \\
\hline
\end{tabular}

${ }^{1}$ Depends on the type of source.

The difference between $\mathrm{CO}_{2}$ and $\mathrm{CO}_{2 \mathrm{e}}$ emissions for liquid fuels is rather small, about $7 \div 9 \%$ more for $\mathrm{CO}_{2 \mathrm{e}}$; it is quite stable and should not be included in further considerations.

The International Maritime Organization (IMO) has an ambition to halve the GHG emissions from shipping by the year 2050 and to decarbonize shipping as soon as possible in this century. Currently, there are only three mandatory requirements addressing GHG emissions:

- The Energy Efficiency Design Index (EEDI) for newbuilds mandating up to $30 \% \mathrm{im}$ provement in design performance depending on ship type and size in comparison with 2013 (year of requirement introduction) [13];

- The Ship Energy Efficiency Management Plan (SEEMP) for all ships above $400 \mathrm{GT}$ in operation [14]; and

- The Fuel Oil Consumption Data Collection System (DCS) mandating annual reporting of carbon dioxide emissions, and other activity data and ship particulars for all ships above 5000 GT.

The next mandatory requirements will be introduced as follows (at MEPC 76 in June 2021):

- The Energy Efficiency Design Index for Existing Ships (EEXI) with expected entry into force on 1 January 2023;

- The Carbon Intensity Indicator (CII) (as AER (Annual Emission Rating) in grams of $\mathrm{CO}_{2}$ per deadweight-mile) with rating scheme from A to $\mathrm{E}$ calculated every year for all cargo and cruise ships above $5000 \mathrm{GT}$; and

- A strengthening of the SEEMP with mandatory content achieving the CII targets. of 2025.

These new proposed requirements for existing ships will be reviewed by the end

\section{Carbon Dioxide Emission Coefficient for Marine and Alternative Fuels}

Carbon dioxide emissions come from the combustion of fuel containing a carbon element. The reaction is exothermic. The heat allows engines to transform it to mechanical energy. 
The carbon element combustion reaction looks as follows:

$$
\mathrm{C}+\mathrm{O}_{2} \rightarrow \mathrm{CO}_{2}+406.92 \mathrm{~kJ} / \mathrm{mol}
$$

One mol of carbon plus one mol of oxygen yields one mol of carbon dioxide and heat.

Approximately, $12 \mathrm{~g}$ of carbon plus $32 \mathrm{~g}$ of oxygen give $44 \mathrm{~g}$ of carbon dioxide. This means that the fuel coefficient $\left(c_{F}\right)$ for the carbon element is $44 / 12=3.667\left(c_{F C}=3.667\right)$ (more precisely, it is 3.6642 if the real mass of elements is taken into consideration). The fuel coefficient depends on the carbon content, CC, (mass to mass $(\mathrm{m} / \mathrm{m})$ ) in the fuel and is equal to the product of the carbon fuel coefficient and carbon content $\left(c_{F F}=c_{F C} \cdot C C\right)$. The coefficients for different marine and alternative fuels are shown in Table 2.

Table 2. Carbon dioxide emission coefficient for different marine and alternative fuels.

\begin{tabular}{ccc}
\hline Type of Fuel & Carbon Content $(\mathbf{m} / \mathbf{m})$ & Fuel Coefficient $\left.\mathbf{~}_{\mathbf{F}}\right)\left(\mathbf{k g ~ C O} \mathbf{~} / \mathbf{k g}\right.$ of Fuel) $\mathbf{~}^{\mathbf{1}}$ \\
\hline Marine gas oil & 0.875 & 3.206 \\
Marine diesel oil & 0.875 & 3.206 \\
Light fuel oil & 0.86 & 3.151 \\
Marine heavy oil & 0.85 & 3.112 \\
Methane & 0.75 & 2.750 \\
Propane & 0.819 & 3.000 \\
Butane & 0.827 & 3.030 \\
Propylene & 0.857 & 3.141 \\
Biodiesel & 0.86 & 3.151 \\
Methanol & 0.375 & 1.375 \\
Ethanol & 0.522 & 1.913 \\
Dimethyl ether & 0.522 & 1.913 \\
Ammonia & 0 & 0 \\
\hline
\end{tabular}

${ }^{1}$ Sometimes, the carbon dioxide emission coefficient is shown using the units $\mathrm{kg} \mathrm{CO}_{2} / \mathrm{MJ}$ or $\mathrm{kg} \mathrm{CO} / \mathrm{kWh}$, where the lower heating value of is taken into consideration.

The total emission of GHGs (mainly $\mathrm{CO}_{2}$ ) from fuels is greater, taking into account the amount of carbon dioxide emission from production, processing and delivery of fuel as the well-to-tank emission (WTT analysis) [15], also known as upstream or indirect emission.

Some researchers (i.e., [16]) have used another coefficient-the well-to-wake carbon dioxide equivalent factor considering the sum of both the well-to-tank and tank-to-wake factors.

\section{Decarbonization Process of Marine Fuels}

The decarbonization of marine fuels is key to meeting the GHG reduction goal set by the IMO [17,18] and other organizations [19-21]. The bunker demand for marine fuels is ca. 370 million tons/year. The decrease in GHG emissions is possible through many diverse operations: improving the engine efficiency, decreasing the vessel hull resistance, slow steaming within certain limits, better planning of vessel voyages, etc. [4]. These operations allow for a decrease in total fuel consumption and, finally, a decrease in equivalent carbon dioxide emissions. The IMO has introduced the Monitoring Reporting Verification (MRV) Regulation for vessels sailing to European ports (entered into force 1 July 2015) and the Data Collection System (DCS) for vessels over 5000 GT (entered into force 1 March 2018) [22]. Many actions have been carried out on vessels by shipowners in order to fulfil the IMO's requirements, such as the optimization of power and propulsion systems, extensive speed optimization (mainly slowing down), voyage optimization, fleet management, logistics and incentives, attempts to use third-generation biofuels, and many others. There is a big problem for shipowners with old vessels (mainly over 20 years old) because the IMO proposal (on MEPC 75, November 2020) is compulsory for the introduction of the Energy Efficiency Design Index for existing ships (EEXI) [17]. The Carbon Intensity Indicator (CII) should be calculated as the annual operational CII and compared with prepared values on a scale from $\mathrm{A}$ (the best) to $\mathrm{E}$ (the worst). The $\mathrm{D}$ or E level attained in the next two years requires efforts to be undertaken in order to reach, at minimum, the $C$ level in the 
following year. Otherwise, the ship may be detained in port, which essentially necessitates its scrapping.

\section{Transitional and Future Fuels in Shipping}

\subsection{Biofuels}

Straight vegetable oils (SVO) have been extracted from plants solely for use as fuels. The direct use of SVO generates some problems for marine diesel medium- and slow-speed engines due to the SVOs' higher viscosity and high boiling point, the creation of carbon deposits inside the engines and damage to the engine lubricants. It has been found that SVOs may be used in blends with conventional fuels in order to mitigate these problems.

A process of transesterification converts various oils (triglycerides) into methyl esters. Glycerol and water are removed as undesirable products. The biodiesel obtained is commonly known as fatty acid methyl esters (FAMEs). Such a biodiesel has a higher flash point and cetane number than conventional diesel and is a more suitable fuel than SVO, leading to better engine performance [23]; however, due to a high cloud point $\left(32{ }^{\circ} \mathrm{C}\right)$, which can result in poor fuel flow and filter clogging, FAMEs are not fully compatible with many existing diesel engines and have a short storage time. The basic parameters of some biofuels are shown in Table 3 .

Table 3. Parameters of some biofuels [24].

\begin{tabular}{cccc}
\hline Parameter/Type of Biofuel & Biodiesel & Renewable Diesel & Fatty acid Methyl Esters \\
\hline Density $\left(15^{\circ} \mathrm{C}\right)\left(\mathrm{kg} / \mathrm{dm}^{3}\right)$ & 0.88 & 0.78 & 0.765 \\
Kinetic viscosity $\left(40^{\circ} \mathrm{C}\right)(\mathrm{cSt})$ & $4 \div 6$ & $2 \div 4$ & 2 \\
Cetane number & $47 \div 65$ & $>70$ & $>70$ \\
Sulfur content (mass $\%)$ & $<0.0015$ & $<0.0005$ & $<0.1$ \\
Lower Heating Value & $37.2 \mathrm{MJ} / \mathrm{kg}$ & $44.1 \mathrm{MJ} / \mathrm{kg}$ & $43 \mathrm{MJ} / \mathrm{kg}$ \\
\hline
\end{tabular}

\subsection{Alcohols}

The challenge of producing fuel from biomass is the high oxygen content and lack of suitability for direct conversion, requiring additional processing steps such as deoxygenation to obtain a high hydrogen-carbon $(\mathrm{H}: \mathrm{C})$ ratio. The final result is that the fuel obtained has a low oxygen content, a low water solubility and a high degree of carbon bond saturation [24]. After the hydroprocessing step, vegetable oils may be converted into hydrotreated esters and fatty acids (HEFA) fuel.

The main products of biomass conversion are alcohols. There are many alcohols that may be taken into consideration as a possible marine fuel, but only two of them are commonly used: methanol and ethanol. Methanol has been used as a fuel for a number of successful marine trials with a possibility to use either spark ignition or compression ignition engines. Ethanol is popular as a car fuel in some countries. The basic parameters of methanol and ethanol are shown in Table 4.

Table 4. Section of the material safety data sheet for methanol and ethanol [25].

\begin{tabular}{ccc}
\hline Parameter & Methanol & Ethanol \\
\hline Density (at $\left.15^{\circ} \mathrm{C}\right)$ & $794 \mathrm{~kg} / \mathrm{m}^{3}$ & $789 \mathrm{~kg} / \mathrm{m}^{3}$ \\
Lower Heating Value & $20 \div 23 \mathrm{MJ} / \mathrm{kg}$ & $27 \div 30 \mathrm{MJ} / \mathrm{kg}$ \\
Boiling point & $64.7^{\circ} \mathrm{C}$ & $77^{\circ} \mathrm{C}$ \\
Flash point & $12^{\circ} \mathrm{C}$ & $<10^{\circ} \mathrm{C}$ \\
Lower and upper explosion limits & $6 \div 36.5 \% \mathrm{v} / \mathrm{v}$ & $3.2 \div 18.3 \% \mathrm{v}$ \\
Water solubility & miscible & miscible \\
Kinetic viscosity at $20^{\circ} \mathrm{C}$ & $0.77 \mathrm{cSt}$ & $1.77 \mathrm{cSt}$ \\
\hline
\end{tabular}

Due to the smaller lower heating value (LHV) of methanol in comparison with marine diesel oil (MDO) (22 to $42 \mathrm{MJ} / \mathrm{kg}$ ) and lower density (794 to $870 \mathrm{~kg} / \mathrm{m}^{3}$ ), the fuel dose should be about twice as high for methanol. 
Methanol is toxic for humans if swallowed or inhaled, and toxic in contact with skin. Due to the low flash point (traditional marine liquid fuels have minimum flash temperature over $60^{\circ} \mathrm{C}$ ), the risk of fire and/or explosion is greater for methanol; additionally, special materials are needed for rubber sealings (methanol resistance plastics, i.e., Teflon type), and methanol is corrosive to copper and nickel, and their alloys [26].

\subsection{Ammonia as a Remedy for the Decarbonization Process}

Ammonia is a synthetic gas obtained from fossil fuels, biomass or renewable sources. Sulfur- and carbon-free ammonia do not emit any sulfur oxides, carbon oxides, particulate matters or unburnt hydrocarbons when combusted. It will bring about the fulfillment of the IMO's emission regulations [17]. It has been considered a potential candidate for a fuel for the future of shipping. The properties of ammonia, in comparison with another possible gas fuel for shipping-propane, are shown in Table 5.

Table 5. Properties of ammonia in comparison with propane [27].

\begin{tabular}{ccc}
\hline Parameter & Ammonia $\mathbf{N H}_{\mathbf{3}}$ & Propane $\mathbf{C}_{\mathbf{3}} \mathbf{H}_{\mathbf{8}}$ \\
\hline Boiling point at 0.1 MPa & $-33.3^{\circ} \mathrm{C}$ & $-42.1{ }^{\circ} \mathrm{C}$ \\
Density, liquid & $682 \mathrm{~kg} / \mathrm{m}^{3}$ & $493 \mathrm{~kg} / \mathrm{m}^{3}$ \\
Lower Heating Value & $18.6 \mathrm{MJ} / \mathrm{kg}$ & $46.6 \mathrm{MJ} / \mathrm{kg}$ \\
Flammability limit ratio, (stoichiometric with air $=1)$ & $0.63 \div 1.4$ & $0.51 \div 2.51$ \\
Maximum burning velocity & $0.09 \mathrm{~m} / \mathrm{s}$ & $0.43 \mathrm{~m} / \mathrm{s}$ \\
Ignition temperature & $651^{\circ} \mathrm{C}$ & $432{ }^{\circ} \mathrm{C}$ \\
Maximum adiabatic flame temperature & $1750{ }^{\circ} \mathrm{C}$ & $2020^{\circ} \mathrm{C}$ \\
Range LFL-UFL & $15 \div 25 \%$ & $2.1 \div 9.5 \%$ \\
Cetane number & Very low & $>34$ \\
\hline
\end{tabular}

Due to some problems with the process of proper ammonia combustion in diesel engines, such as its very low burning velocity, very high autoignition temperature and rather small Lower Heating Value, there is a minor contribution from the pilot fuel injection (traditional liquid fuel-marine diesel oil), which has the purpose of ensuring timed and controlled combustion of ammonia $[27,28]$. In that case, a small level of $\mathrm{CO}_{2}$ emissions will occur.

The two-stroke ammonia concept is an add-on to the ME family of MAN B\&W engines: ME-LGIP (LPG) for the injection of liquid propane and ME-LGIM for the injection of liquid methanol [27]. Many problems with ammonia as a marine fuel have already been solved, and a positive trial on a laboratory two-stroke, low-speed engine has been performed.

Ammonia is commonly stored in a liquid state at ambient temperature in pressurized tanks at pressure above 8.6 bar (abs) (at $20^{\circ} \mathrm{C}$ ) or at 17 bar (abs) (at temperatures over $20{ }^{\circ} \mathrm{C}$ ). There is a low risk of fire due to the high level of LFL and no risk of explosion. It is worth stating that the infrastructure for storage and distribution of ammonia already exists and can be adopted as quickly as possible for ships bunkering [29-32].

\subsection{Marine Gaseous Fuels-Dual or Tri Fuel Engines}

Marine diesel engines are prepared for the combustion of traditional marine fuels: marine heavy, diesel and gas oils. The combustion of blended fuels containing biofuels is possible after an adaptation of an engine fuel system. Dual (DF) or tri (TF) fuel engine means that it has been optimized for combustion of other fuels, such as methane, ethane, propane, butane and propylene originating from vessel cargo containment tanks or, in some cases, directly from special fuel tanks. DF or TF engines allow for the use of the boil-off gas (BOG) originating from liquefied natural gas (LNG) and liquid petroleum gas (LPG) carriers as a fuel. IMO Resolution MSC 39(95) prepared the adoption of the International Code of Safety for Ship Using Gases or Other Low-flashpoint Fuels (IGF Code) in 2015 [33].

Shipowners have a choice between two different engine solutions for two-stroke, low-speed propulsion for LNG carriers: MEGI (high-pressure gas injection), MAN Diesel 
\& Turbo and X-DF (low-pressure gas admission) by WinGD (previously Wartsila). The MEGI system operates on the diesel cycle, and the X-DF system operates on the Otto cycle. Both systems require simultaneous micro-pilot injection of MDO with the natural gas admission [32]. The environmental advantage of natural gas due to the smaller carbon fuel coefficient (Table 1), bigger than HFO and LHV but about $25 \%$ smaller $\mathrm{CO}_{2}$ emission in combustion, is lost because of methane escape (slip) to the atmosphere. As a result, the well-to-tank $\mathrm{CO}_{2 \mathrm{e}}$ emission is often bigger for natural gas $[15,16]$. DF diesel engines prepared for methane combustion may be optimized to burn the ethane. Therefore, there are two possibilities for such DF engines: to combust liquid fuel and methane, or liquid fuel and ethane within the range from 0 to $100 \%$ of any mixture during engine operation up to $80 \%$ of nominal power during fuel change.

Other LPG fuels (propane, butane and propylene) and their mixtures may be used in marine diesel engines after their adaptation during the construction process of a new engine (only for specific engine types, i.e., ME-LGI type MAN engines with a spark plug or pilot fuel injection for ignition, or the Wartsila 34SG-LPG engine, fueled by propane, could also be used with pilot fuel injection in a DF configuration) on commission from the shipowner or the shipyard. The carbon fuel coefficient for LPG fuels is similar to that of typical marine fuels and makes a $17 \%$ difference in $\mathrm{CO}_{2}$ emission due to the higher LHV in comparison with HFO [34]. To maintain a safe knock margin for all gaseous fuels, the minimum cetane number of a fuel is required depending on the fuel type. Combustion of gaseous fuels in marine diesel engines meets the IMO requirements of Tier 3 emission [35] without using the selective catalytic reduction (SCR) or exhaust gas recirculation (EGR) cleaning systems.

\subsection{Hydrogen-Marine Fuel of the Future}

Hydrogen seems to be potentially the best fuel for many purposes because only water vapor is produced as a result of combustion. It has a very high LHV, about three times bigger than traditional marine fuels. The higher heating value (HHV) is $141.8 \mathrm{MJ} / \mathrm{kg}$. Hydrogen is a fuel from which combustion allows for the attainment of the most heat energy per $1 \mathrm{~kg}$ of mass. Hydrogen can be made from a wide range of sources, including water electrolysis [36]. The main problem is its low density in the gaseous as well as in the liquid states. The properties of hydrogen in comparison with methane are shown in Table 6 . It can be seen that a very low critical temperature $\left(-240^{\circ} \mathrm{C}\right.$, about $\left.33 \mathrm{~K}\right)$ is a condition of hydrogen liquefaction [37]. Long-term hydrogen storage poses a number of more serious problems than in the case of other gaseous fuels.

Table 6. Properties of hydrogen in comparison to methane $[37,38]$.

\begin{tabular}{ccc}
\hline Parameter & Hydrogen & Methane (Natural Gas) \\
\hline Gas density at normal conditions (ISO) & $0.0905 \mathrm{~kg} / \mathrm{m}^{3}$ & $0.716 \mathrm{~kg} / \mathrm{m}^{3}$ \\
Relative density, gas (air = 1) & 0.07 & 0.554 \\
Relative density, liquid (water $=1)$ & 0.071 & $0.44 \div 0.48$ \\
Lower Heating Value & $119.96 \mathrm{MJ} / \mathrm{kg}$ & $50 \mathrm{MJ} / \mathrm{kg}$ \\
Critical temperature & $-240^{\circ} \mathrm{C}$ & $-82.45^{\circ} \mathrm{C}$ \\
Boiling point & $-253^{\circ} \mathrm{C}$ & $-161.48^{\circ} \mathrm{C}$ \\
Melting point & $-259^{\circ} \mathrm{C}$ & $-187.6^{\circ} \mathrm{C}$ \\
Flammability range & $4 \div 7 \%^{\circ}(\mathrm{v} / \mathrm{v})$ & $5 \div 14^{\circ}(\mathrm{v} / \mathrm{v})$ \\
Maximum burning velocity & $2.91 \mathrm{~m} / \mathrm{s}$ & $0.37 \mathrm{~m} / \mathrm{s}$ \\
Autoignition temperature & $585^{\circ} \mathrm{C}$ & $537^{\circ} \mathrm{C}$ \\
UN & 1954 & 1971 \\
\hline & Burns with invisible & \\
Other information & flame, extremely & Asphyxiant \\
& flammable gas & \\
\hline
\end{tabular}

There is a lack of adequate technologies to use hydrogen as a marine fuel (i.e., see the maximum burning velocity). It is worth stating that the energy content of hydrogen is 
8.5 MJ $/ \mathrm{dm}^{3}$ (liquefied, $-253^{\circ} \mathrm{C}$ ) and $2.46 \mathrm{MJ} / \mathrm{dm}^{3}$ (compressed, $30 \mathrm{MPa}$ ) in comparison with liquefied ammonia, $12.69 \mathrm{MJ} / \mathrm{dm}^{3}$ (liquefied, $-33^{\circ} \mathrm{C}$ ). Due to many advantages and problems with the use of gaseous hydrogen as fuel, attempts have been made to produce gas mixtures containing an admixture of hydrogen in quantities of up to $30 \%$. An alternative option, offered by Wartsila to utilize LPG for propulsion, is the installation of a gas reformer to turn LPG and steam into methane in a mixture with $\mathrm{CO}_{2}$ and some hydrogen. The reformed gas is sufficient for a regular gas or dual-fuel engine to be used with no need for engine derating [36].

The use of hydrogen in thermal engines is an intermediate solution. The overarching objective will be its use in fuel cells.

\section{Possible Scenarios of Marine Fuel Usage}

During the last 50 years, world fuel crises have occurred a few times. The increased price of marine fuel has had an influence on the economic cost of ship operation. Now, the share of fuel cost reaches about $70 \%$ of the total operational cost. Shipowners started using the cheapest fuel possible-heavy fuel oils. The environmental IMO regulations have changed the approach to the use of fuels. The decarbonization process of marine fuels started in 2020. IMO expects total GHG emissions from shipping to be at least halved by the year 2050. A range of transitional fuels will be used between 2022 and 2050. Researchers, shipping companies and classification societies provide different scenarios for the contribution of marine fuel types in shipping [39-42]. In the years to come (2022-2030), the IMO regulations will have a decisive impact on the use of preferred marine fuels considered greener.

An example of possible scenarios for the contribution of different fuel types to the shipping market is given in Figure 1. The DNV report [43] presents 30 scenarios for the use of marine fuels by 2050. The scenarios express extreme views. Two DNV scenarios (No. 11 and No. 19) and one of my own were selected to show the differences (Figure 1).

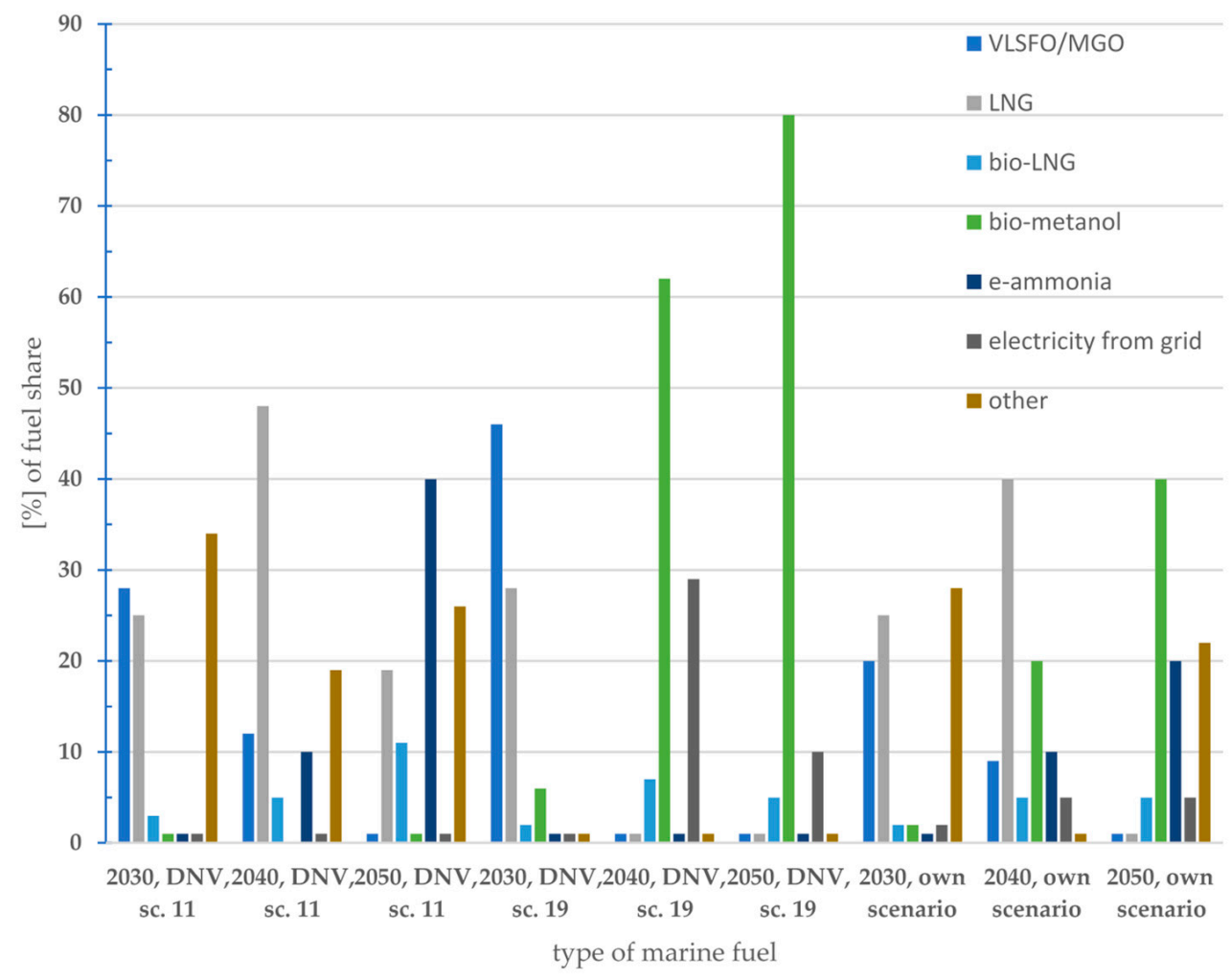

Figure 1. Possible scenarios for the contribution of different marine fuel types to the shipping market by 2050 (on the base 43 and own elaboration). (VLSFO/MGO—very low sulfur fuel oil/marine gas oil; HFO—heavy fuel oil; LNG—liquefied natural gas). 
It is believed that the development of hydrogen technologies will be a breakthrough in shipping after 2040 [44] but, in my opinion, after 2050.

\section{Discussion-What Type of Marine Fuel Will Be Used in the Future?}

The search for marine fuel will meet a number of often contradictory requirements. The main action is to adapt marine diesel engines to burn fuels that will be considered ecologically clean, do not impair the performance of the engine, are available in adequate quantity and are preferably inexpensive.

A natural carbon cycle is needed for life on Earth. The IMO's goal is not to go "zero carbon" but to decrease and finally stop moving carbon from fossil fuels into the natural carbon cycle. The IMO's action is to reduce the GHG emissions in the atmosphere in order to reduce the rate of increase in concentration of mainly carbon dioxide. There are no "green" or "black" atoms of carbon. The problem is the mass balance of $\mathrm{CO}_{2}$ in the atmosphere. The decarbonization process does not mean removing all carbon compounds from the atmosphere but reducing the use of fossil fuels in shipping.

The reduction in marine fuel consumption is possible through an increase in the efficiency of diesel engines and gas turbines. The efficiency of thermal engines is limited by the efficiency of the Carnot cycle (up to a maximum of about 70\%). The efficiency of marine diesel engines for ship propulsion reported by the manufacturers reached a value of $50 \div 53 \%$ [44].

The primary way to decarbonize shipping is to use fuels with little or no carbon content. Many assessments are being made on the possibility of new marine fuels being compliant with the IMO's requirements as well as the availability of fuels, their characteristics and available technologies [11,45-47]. It seems necessary to move away from the use of thermal engines on ships in favor of fuel cells and electricity batteries. In this case, the type of marine fuel of the future in shipping is less important. The development of technologies based on direct electricity generation and long-term storage of electricity will be decided.

There must be a process of moving away from traditional marine fuels in favor of increasing the share of gaseous fuels. During the transitional period, natural gas and ammonia will be the main replacement fuels. In about $20 \div 30$ years, the hydrogen era will come.

\section{Conclusions}

One of the IMO actions was to define the EEDI and EEOI indicators and then to gradually reduce carbon dioxide emissions by setting limits to be met by ships under construction and in operation. Ship designers and shipowners should take a number of measures to meet the requirements. It turns out that, for many ships in operation, it will be generally impossible to meet specified requirements, which puts shipowners in a very bad position when deciding whether to upgrade or scrap the ship.

The efficiency of fuel cells reaches $99 \%$. The development of hydrogen fuel cell technology as a primary energy source is a technology of the future. The problems of negative environmental impact will be transferred from shipping to onshore plants producing batteries, and the production and storage of hydrogen.

Battery-electric propulsion with an additional generator of electricity in the form of fuel cells appears to be the most efficient use of primary energy (ammonia, methanol and hydrogen). Shipping would require around $25 \%$ of additional electricity generation originating from renewable sources from onshore power plants.

Electric ships are typically smaller and mostly engaged in coastal short-sea-shipping (SSS). The technology is readily available for bigger vessels and longer voyages.

Carbon dioxide emissions depend on the chemical composition of the fuel, its Lower Heating Value and the engine efficiency. Since synthetic fuels may have a similar chemical composition, emissions will be the same. The problem of not counting the emissions from biofuels remains. The problem of rapid recognition of traditional or synthetic fuels is becoming more serious, especially in the case of blended fuels (their mixtures). 
Funding: This research received no external funding.

Institutional Review Board Statement: Not Applicable.

Informed Consent Statement: Not Applicable.

Data Availability Statement: Not Applicable.

Conflicts of Interest: The author declares no conflict of interest.

\section{References}

1. Olmer, N.; Comer, B.; Roy, B.; Mao, X.; Rutherford, D. Greenhouse Gas Emission from Global Shipping 2013-2015, Detailed Methodology; The International Council on Clean Transportation: Washington, DC, USA, 2017.

2. IMO MEPC 72/INF.5. Reduction of GHG from Ships. Understanding $\mathrm{CO}_{2}$ Emissions and Challenges in Assessing the Operational Efficiency for Ships; International Maritime Organization: London, UK, 2018.

3. IMO (International Maritime Organization). 2019. Available online: http://www.imo.org/en/OurWork/Environment/ PollutionPrevention/AirPollution/Pages/GHG-Emissions.aspx (accessed on 15 March 2021).

4. IMO. IMO Action to Reduce Greenhouse Gas Emission from International Shipping; International Maritime Organization: London, $\mathrm{UK}, 2018$.

5. Hyungju, K.; Kwi, Y.K.; Tae-Hwan, J. A study on a necessity of integrated evaluation of alternative marine fuels. J. Int. Marit. Saf. Environ. Aff. Shipp. 2020, 4, 26-31. [CrossRef]

6. Liu, M.; Li, C.; Koh, E.K.; Ang, Z.; Lam, J.S.L. Is methanol a future marine fuel for shipping? IOP Conf. Ser. J. Phys. 2019, 1357. [CrossRef]

7. Zincir, B. A short review of ammonia as an alternative marine fuel for decarbonized maritime transportation. In Proceedings of the ICEESEN, Kayseri, Turkey, 19-21 November 2020.

8. DNV. Bio Diesel: Emissions Depend on the Production Method; DNV GL: Bærum, Norway, 2018.

9. Available online: http://www.ppmc-transport.org/battery-electric-car-ferry-in-norway/ (accessed on 19 May 2021).

10. Global Warming Potential Values. Greenhouse Gas. Protocol. 2016. Available online: https://www.ghgprotocol.org/sites/ default/files/ghgp/Global-Warming-Potential-Values\%20\%28Feb\%2016\%202016\%29_1.pdf (accessed on 17 May 2021).

11. EPA. Emission Factors for Greenhouse Gas Inventories. United States Environmental Protection Agency. 2020. Available online: https:/ / www.epa.gov/sites/production/files/2020-04/documents/ghg-emission-factors-hub.pdf (accessed on 22 May 2021).

12. Hodnebrog, O.; Dalsoren, S.B.; Hyhre, G. Lifetimes, direct and indirect radiative forcing, and global warming potentials of ethane $\left(\mathrm{C}_{2} \mathrm{H}_{6}\right)$, propane $\left(\mathrm{C}_{3} \mathrm{H}_{8}\right)$ and butane $\left(\mathrm{C}_{4} \mathrm{H}_{10}\right)$. Atmos. Sci. Lett. 2018, 19, e804. [CrossRef]

13. IMO Resolution MEPC.2015(63). Guidelines for Calculation of Reference Lines for Use with EEDI; International Maritime Organization: London, UK, 2012.

14. IMO MEPC 59/24/Add.1, Annex 19. Guidance for the Development of a Ship Energy Efficiency Management Plan, SEEMP; International Maritime Organization: London, UK, 2012.

15. Greene, S.; Jia, H.; Rubio-Domingo, G. Well-to-tank carbon emission from crude oil maritime transportation. Transp. Res. Part. D 2020, 88, 102587. [CrossRef]

16. Comer, B.; Osipova, L. Accounting Well-To-Wake Carbon Dioxide Equivalent Emission in Maritime Transportation Climate Policies. The International Council on Clean Transportation, ICCT. 2021. Available online: https://theicct.org/publications/wellto-wake-co2-mar2021 (accessed on 17 May 2021).

17. IMO MEPC 75/7/15. Reduction of GHG Emissions from Ships. Fourth IMO GHG Study 2020-Final Report; International Maritime Organization: London, UK, 2020.

18. IMO, Marine Environment Protection Committee. Initial IMO Strategy on Reduction of GHG Emission from Ships; International Maritime Organization: London, UK, 2018.

19. Roadmap to Decarbonizing European Shipping. Transport \& Environment. 2018. Available online: https://www.transportenvironment. org/publications/roadmap-decarbonising-european-shipping (accessed on 21 May 2021).

20. Reaching Zero Carbon Emissions from Shipping. ETC Energy Transitions Commission. 2018. Available online: https://www.ieta. org/resources/COP24/Misc\%20Media\%20Files/Dec7/SE16\%20(3).pdf (accessed on 22 May 2021).

21. Balcombe, P.; Brierley, J.; Lewis, C.; Skatvedt, L.; Speirs, J.; Hawkes, A.; Staffell, I. How to decarbonise international shipping: Options for fuels, technologies and policies. Energy Convers. Manag. 2019, 182, 72-88. [CrossRef]

22. IMO (International Maritime Organization). 2018. Available online: http://www.imo.org/en/ourwork/environment/pollutionprevention/ airpollution/pages/data-collection-system.aspx (accessed on 29 May 2021).

23. Witkowski, K. Research of the effectiveness of selected methods of reducing toxic exhaust emissions of marine diesel engines. J. Mar. Sci. Eng. 2020, 8, 452. [CrossRef]

24. Kass, M.; Abdullah, Z.; Biddy, M.J.; Drennan, C.; Haq, Z.; Hawkins, T.; Jones, S.; Holliday, J.; Longman, D.E.; Menter, S.; et al. Understanding the Opportunities of Biofuels for Marine Shipping. Oak Ridge National Laboratory. 2018. Available online: https:/ /info.ornl.gov/sites/publications/Files/pub120597.pdf. (accessed on 14 May 2021).

25. Hsieh, C.C.; Felby, C. Biofuels for the Marine Shipping Sector. IEA Bioenergy. 2017. Available online: https://www.ieabioenergy. com/wp-content/uploads/2018/02/Marine-biofuel-report-final-Oct-2017.pdf. (accessed on 20 May 2021). 
26. Andersson, K.; Salazar, C.M. Methanol as a Marine Fuel Report. 2015. Available online: https://www.methanol.org/wp-content/ uploads /2018/03/FCBI-Methanol-Marine-Fuel-Report-Final-English.pdf (accessed on 14 May 2021).

27. Engineering the Future Two-Stroke Green-Ammonia Engine. MAN Energy Solutions. 2019. Available online: https://fathom. world/wp-content/uploads/2020/05/engineeringthefuturetwostrokegreenammoniaengine1589339239488.pdf. (accessed on 14 May 2021).

28. IMO CCC 7/INF8. Forecasting the Alternative Fuel. Ammonia; International Maritime Organization: London, UK, 2020.

29. ABS. Ammonia as Marine Fuel, Sustainability Whitepaper; ABS: Spring, TX, USA, 2020.

30. DNV. Ammonia as A Marine Fuel, Safety Handbook; DNV-GL: Bærum, Norway, 2020.

31. Hansson, J.; Brynolf, S.; Fridell, E.; Lehtveer, M. The potential role of ammonia as marine fuel-based on energy system modelling and multi-criteria decision analysis. Sustainability 2020, 12, 3265. [CrossRef]

32. DNV. Assessment of Selected Alternative Fuels and Technologies; DNV-GL Maritime: Bærum, Norway, 2019.

33. IMO Resolution MSC 39(95). Adoption of the International Code for the Ships Using Gases Other Low-Flashpoint Fuels (IGF Code), Adopted 11 June 2015; International Maritime Organization: London, UK, 2015.

34. DNV. LPG as a Marine Fuel; Group Technology \& Research, DNV-GL: Bærum, Norway, 2017.

35. IMO. International Convention for the Prevention of Pollution from Ships, Revised MARPOL Annex VI; International Maritime Organization: London, UK, 2008.

36. Bouman, E.A.; Lindstad, E.; Rialland, A.I.; Strømman, A.H. State-of-the-art technologies, measures, and potential for reducing GHG emissions from shipping-A review. Transp. Res. Part D 2017, 52, 408-421. [CrossRef]

37. Available online: http://alsafetydatasheets.com/download/se/Hydrogen_compressed-SE_ENG.pdf (accessed on 27 May 2021).

38. Available online: https:/ / www.airgas.com/msds/001033.pdf (accessed on 27 May 2021).

39. Sadik-Zada, E.R.; Gatto, A. Energy security pathways in South East Europe: Diversification of the natural gas supplies, energy transition, and energy futures. In Economic to Energy Transition. Energy, Climate and the Environment; Mišík, M., Oravcová, V., Eds.; Palgrave Macmillan: Cham, Switzerland, 2021. [CrossRef]

40. Lloyds Register Marine. Global Marine Fuel Trends 2030; Lloyd's Register: London, UK, 2021.

41. Available online: https://www.wfw.com/articles/alternative-fuels-what-does-the-future-hold-for-shipping/ (accessed on 5 July 2021).

42. DNV. 2020 Fuels and Beyond; DNV: Bærum, Norway, 2020.

43. DNV. Maritime Forecast to 2050, Energy Transition Outlook 2020; DNV: Bærum, Norway, 2020.

44. DNV. Rising to the Challenge of Hydrogen Economy; DNV: Bærum, Norway, 2021.

45. Winterthur Gas \& Diesel Ltd. 2021. Available online: https://www.wingd.com/en/documents/general/brochures/wingd-lowspeed-engines-booklet-2021.pdf/ (accessed on 28 May 2021).

46. Bengtsson, S.; Andersson, K.; Fridell, E. A comparative life cycle assessment of marine fuels liquefied natural gas and three other fossil fuels. Proc. Inst. Mech. Eng. Part M J. Eng. Marit. Environ. 2011, 225, 97-110.

47. Andersson, K.; Brynolf, S.; Hansson, J.; Grahn, M. Criteria and decision support for a sustainable choice of alternative marine fuels. Sustainability 2020, 12, 3623. [CrossRef] 